University of Nebraska - Lincoln

DigitalCommons@University of Nebraska - Lincoln

Faculty Publications from the Harold W. Manter Laboratory of Parasitology

8-2003

Bakkeius moragai n. gen. et n. sp. and Pojmanskia riosae n. gen. et $\mathrm{n}$. sp. (Trematoda: Digenea: Brachylaimoidea) in Birds from the Área de Conservación Guanacaste, Costa Rica

\author{
David Zamparo \\ University of Toronto \\ Daniel R. Brooks \\ University of Toronto,dnlbrooks@gmail.com \\ Douglas Causey \\ University of Alaska Anchorage, dcausey@uaa.alaska.edu
}

Follow this and additional works at: https://digitalcommons.unl.edu/parasitologyfacpubs

Part of the Parasitology Commons

Zamparo, David; Brooks, Daniel R.; and Causey, Douglas, "Bakkeius moragai n. gen. et n. sp. and Pojmanskia riosae n. gen. et $\mathrm{n}$. sp. (Trematoda: Digenea: Brachylaimoidea) in Birds from the Área de Conservación Guanacaste, Costa Rica" (2003). Faculty Publications from the Harold W. Manter Laboratory of Parasitology. 237.

https://digitalcommons.unl.edu/parasitologyfacpubs/237

This Article is brought to you for free and open access by the Parasitology, Harold W. Manter Laboratory of at DigitalCommons@University of Nebraska - Lincoln. It has been accepted for inclusion in Faculty Publications from the Harold W. Manter Laboratory of Parasitology by an authorized administrator of DigitalCommons@University of Nebraska - Lincoln. 


\title{
BAKKEIUS MORAGAI N. GEN. ET N. SP. AND POJMANSKIA RIOSAE N. GEN. ET N. SP. (TREMATODA: DIGENEA: BRACHYLAIMOIDEA) IN BIRDS FROM THE AREA DE CONSERVACIÓN GUANACASTE, COSTA RICA
}

\author{
David Zamparo, Daniel R. Brooks, and Douglas Causey* \\ Department of Zoology, University of Toronto, Toronto, Ontario M5S 3G5, Canada. e-mail: zamparo@zoo.utoronto.ca
}

\begin{abstract}
We describe 2 new species of leucochloridiid-like brachylaimoid digeneans parasitizing a variety of birds in the Area de Conservación Guanacaste, Costa Rica, each of which we assign to a new genus. According to Pojmanska's (Pojmanska, T. 2002a. Superfamily Brachylaimoidea Joyeux \& Foley, 1930. In Keys to the Trematoda, D. I. Gibson, A. Jones, and R. A. Bray [eds.]. CAB International and The Natural History Museum, London, U.K., p. 31-36.) key for the Brachylaimoidea, we are unable to place either species in any family. One species most closely resembles members of Leucochloridium by having welldeveloped suckers, lacking an esophagus, and having cecal shoulders, gonads at the posterior end, and the genital pore at posterior end of body but differs by having symmetrical testes, a posttesticular ovary, and a terminal genital pore; thus, we propose the genus Bakkeius for it. The second new genus resembles members of Michajlovia by having ventral genital pores but differs by having extracecal uterine loops in the forebody, a cirrus sac containing the pars prostatica and seminal vesicle, and gland cells surrounding the genital pore; thus, we propose Pojmanskia for it. These new genera must currently be treated as incertae sedis according to Pojmanska (op. cit.); however, we feel that future phylogenetic analyses will require emendation of the family diagnosis for Leucochloridiidae to include those taxa with terminal and ventral genital pores and with preovarian testes.
\end{abstract}

Species constituting the digenean superfamily Leucochloridiidae inhabit a variety of avian hosts, primarily passeriforms, throughout the world. They are best known for the remarkable coloration and behavior of the sporocyst stage occurring in the molluscan intermediate host, long considered a prime example of parasite behavior affecting host appearance and behavior in such a way as to enhance the chance of parasite transmission (Moore, 2002). Several researchers (Pojmanska, 1967, 1969; Bakke, 1980) noted that the color and structure of those sporocysts were phylogenetically conservative enough to be useful as taxonomic characters, complementing the traditional characters drawn from adult morphology. Herein, we describe 2 new species of leucochloridiids parasitizing some birds in the Area de Conservación Guanacaste (ACG) (http://www.acguanacaste.ac.cr) in northwestern Costa Rica, for which we propose new genera. This study also constitutes part of an effort to perform an inventory of all eukaryotic parasites of all 940 species of vertebrates living within the ACG (http://brooksweb.zoo.utoronto.ca/index.html).

\section{MATERIALS AND METHODS}

Refer to Zamparo et al. (2003a).

\section{DESCRIPTION}

\section{Bakkeius n. gen.}

Diagnosis: Digenea: Brachylaimoidea. Body elongate. Suckers well developed. Esophagus and prepharynx lacking. Pharynx well developed. Ceca extending anteriorly alongside pharynx before turning posteriorly, extending to near posterior end of body. Testes symmetrical Genital pore terminal. Cirrus sac containing cirrus, pars prostatica, and internal seminal vesicle, external seminal vesicle absent. Ovary intercecal, posttesticular. Seminal receptacle formed by expansion of Laure canal. Uterus with extracecal loops in forebody, loops not crossing dorsal to ventral sucker. Metraterm short, straight, highly muscular. Vitelline follicles extending in 2 lateral extracecal fields nearly entire length of body. Excretory vesicle Y-shaped, with short central stem bifurcating posterior to ends of ceca. Excretory pore terminal. Type species Bakkeius moragai $\mathrm{n}$. sp.

Received 9 October 2002; revised 5 March 2003; accepted

* Museum of Comparative Zoology, Harvard University, Cambridge, Massachusetts.
Bakkeius moragai n. sp.

(Figs. 1-3)

Description (based on 28 specimens, 24 measured): Body elongate with rounded ends, 2.2-2.8 (2.6) $\mathrm{mm}$ long, $0.8-1.2$ (1.1) $\mathrm{mm}$ wide. Maximum width just posterior to midbody. Oral sucker subterminal, rounded, 444-577 (497) long, 444-599 (513) wide. Prepharynx and esophagus absent. Pharynx 152-209 (174) long, 152-217 (183) wide, partly overlapped by oral sucker. Oral sucker width:pharynx width ratio 1:0.34-0.43 (1:0.41). Ceca bifurcating immediately posterior to pharynx, ceca ascending to oral sucker region before descending. Ceca long and narrow, occupying $88-96 \%$ (92\%) of total body length (TBL). Ventral sucker equatorial, 518-703 (580) long, 496-681 (567) wide. Oral sucker:ventral sucker width ratio 1:0.93-1.12 (1:1.01). Testes symmetrical, lobed, intercecal, anterior margin immediately posterior to posterior margin of ventral sucker, 58-68\% (63\%) TBL from anterior end, 171-444 (290) long by 152-370 (226) wide. Cirrus sac posteromedially curved, 190-285 (215) long, 54-133 (89) wide, containing cirrus, pars prostatica, and internal seminal vesicle (Fig. 2). Genital pore terminal, opening into shallow genital atrium into which genital ducts open independently, surrounded by gland cells free in parenchyma. Ovary spherical with smooth margins, posterior to dextral testis, 147-224 (200) long by 141-228 (188) wide. Mehlis gland posterior to ovary, dorsal to seminal receptacle. Seminal receptacle formed by saccate expansion of Laurer canal, separated from ovary by Mehlis gland and ootype, opening into ootype distal from common vitelline duct (Fig. 3). Uterus extending anteriorly from ootype along dextral side of body, overlapping ceca ventrally, lacking uterine loops dorsal to ventral sucker, with extracecal loops in forebody to midlevel of oral sucker, 11$15 \%(14 \%)$ TBL from anterior end; extending posteriorly along sinistral side, then medially between testes and sinistral side of body, with some uterine loops posterior to ootype complex. Metraterm curved laterally, 171-266 (222) long by 76-125 (99) wide, never overlapping ceca, surrounded by small gland cells on surface and large gland cells free in parenchyma. Vitelline fields extending from $14-21 \%$ (17\%) TBL from anterior end to $84-91 \%$ (87\%) TBL from anterior end. Eggs 18-24 long and 13-17 wide, light yellow to dark brown in color. Excretory pore terminal, surrounded by glands free in the parenchyma. Excretory bladder short and narrow, bifurcating at posterior ends of ceca.

\section{Taxonomic summary}

Type host: Gymnopithys leucaspis (Passeriformes: Formicariidae).

Other hosts: Phaenostictus mcleannani (Passeriformes: Formicariidae), Henicorhina leucosticta (Passeriformes: Troglodytidae), and Thryothorus pleurostictus (Passeriformes: Troglodytidae).

Prevalence, intensity, and site of infection: Phaenostictus mcleannani ( 2 of 3; 7, 4 worms; gallbladder); G. leucaspis (3 of 8; 1, 4, 5 worms; small intestine); $H$. leucosticta ( 2 of $11 ; 1,6$ worms; 1 in gallbladder 

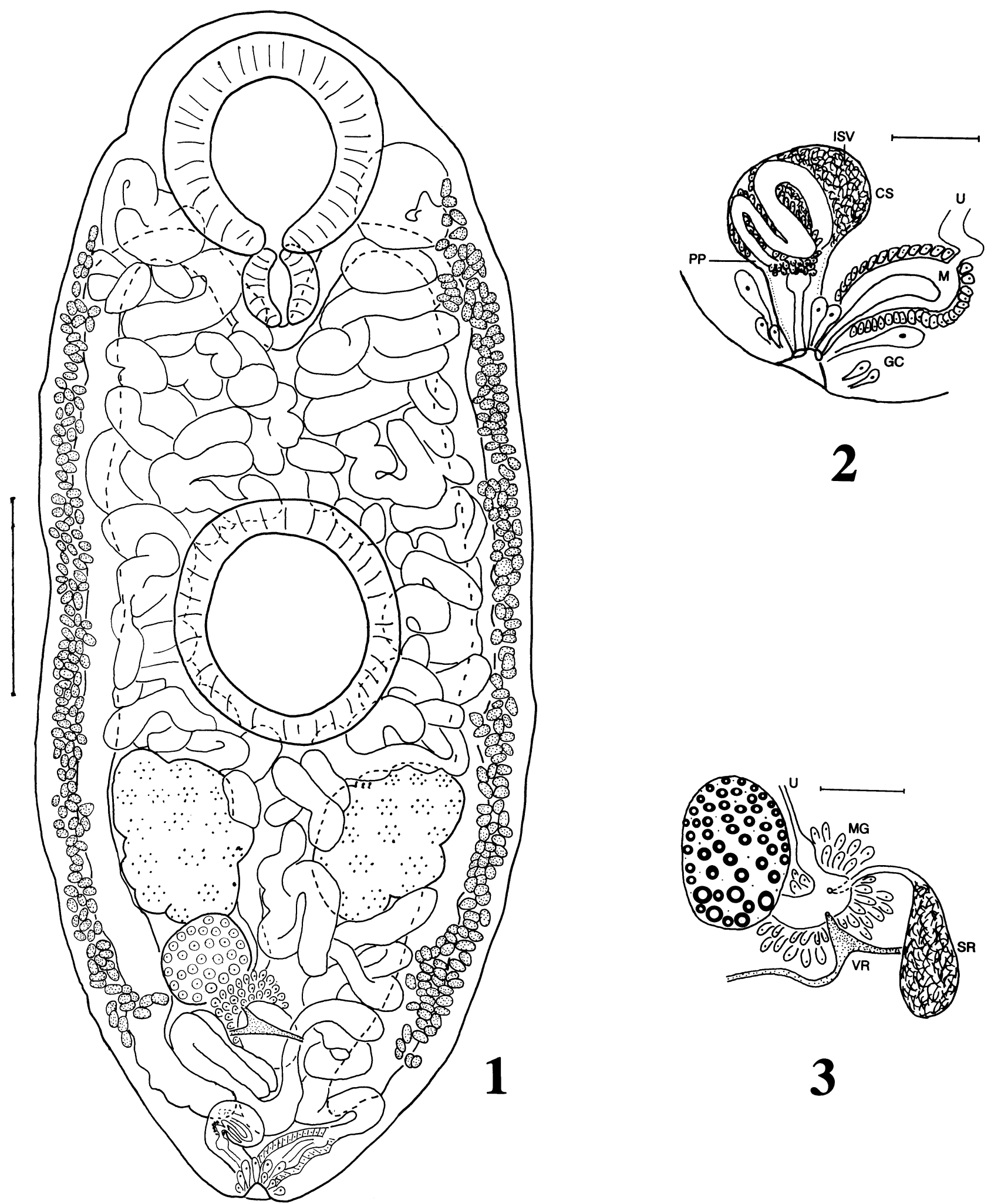

2
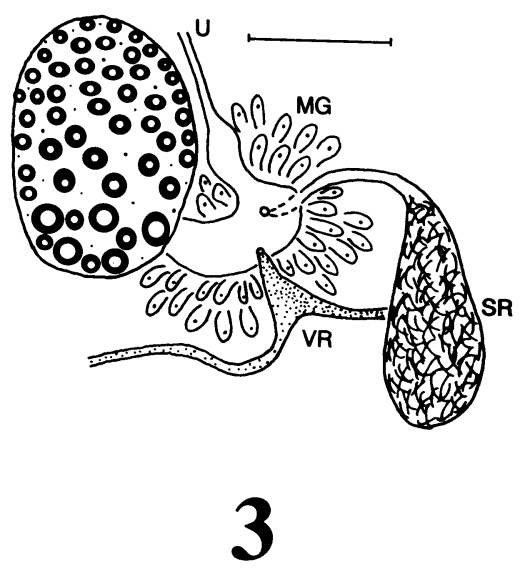

FIGURES 1-3. Bakkeius moragai $n$. sp. 1. Ventral view of whole mount. Bar $=500 \mu \mathrm{m}$. 2. Terminal male reproductive complex, ventral view. Bar $=100 \mu \mathrm{m} . \mathrm{CS}=$ cirrus sac; $\mathrm{GC}=$ gland cells free in parenchyma; $\mathrm{ISV}=$ internal seminal vesicle; $\mathbf{M}=$ metraterm (note additional small gland cells adhering to outer wall); $\mathrm{PP}=$ pars prostatica; $\mathrm{U}=$ uterus. 3. Female reproductive complex, ventral view. Bar $=100 \mu \mathrm{m}$. $\mathrm{MG}=$ Mehlis gland; $\mathrm{SR}=$ seminal receptacle; $\mathrm{U}=$ uterus; $\mathrm{VR}=$ vitelline reservoir. 
and 5 in intestine, 1 in gallbladder); $T$. pleurostictus ( 2 of $9 ; 4,1$ worms; large intestine).

Type locality: Estacion San Gerardo $\left(10^{\circ} 52^{\prime} 50^{\prime \prime} \mathrm{N}, 85^{\circ} 23^{\prime} 21^{\prime \prime} \mathrm{W} ; 605\right.$ $\mathrm{m})$.

Other localities: Maritza $\left(10^{\circ} 57^{\prime} 40^{\prime \prime} \mathrm{N}, 85^{\circ} 28^{\prime} 30^{\prime \prime} \mathrm{W}\right.$; $\left.610 \mathrm{~m}\right)$; Sendero las Parcela, Cafetal $\left(10^{\circ} 51^{\prime} 13^{\prime \prime} \mathrm{N}, 85^{\circ} 36^{\prime} 32^{\prime \prime} \mathrm{W} ; 320 \mathrm{~m}\right)$.

Type material: Holotype, USNPC 93192; paratypes, USNPC no. 93193

Etymology: The new genus is named after Dr. Tor Bakke, in recognition of his many years of study of leucochloridiids. The species is named after Sr. Calixto Moraga, ACG parataxonomist, in recognition of his outstanding efforts on behalf of the parasite inventory.

\section{Remarks}

Using Pojmanska's (2002a, 2002b) recent keys to the Brachylaimoidea, we are unable to place the new species in any family. In having symmetrical testes and a posttesticular ovary, the new species bears some resemblance to the monotypic Thapariella Srivastava, 1953 , which Pojmanksa (2002a, 2002b) placed in its own family, Thapariellidae Srivastava, 1953. Thapariella differs from the new species, however, in having uterine loops and vitellaria confined to the posttesticular space. The new species also bears some resemblance to Michajlovia Pojmanska, 1973, originally placed in the Leucochloridiidae (Pojmanska, 1973) but more recently considered as incertae sedis within the Brachylaimoidea (Pojmanska, 2002a, 2002b). Bakkeius moragai differs from Michajlovia spp. in having symmetrical rather than oblique testes; a posttesticular ovary; a terminal rather than ventral genital pore; uterine loops extending anterior to the cecal shoulders; uterine loops not dorsal to the ventral sucker; and a cirrus sac that contains the cirrus, pars prostatica, and seminal vesicle rather than just the pars prostatica and cirrus. Bakkeius moragai most closely resembles members of Leucochloridium in lacking an esophagus and in having well-developed suckers, cecal shoulders, vitelline follicles extending well into the forebody, gonads in the posterior third of the body, and genitalia at the posterior end of body but differs in having symmetrical rather than oblique testes, a posttesticular ovary rather than an ovary between the testes or opposite the anterior testis, and a terminal rather than a dorsal genital pore.

\section{Pojmanskia n. gen.}

Diagnosis: Digenea: Brachylaimoidea. Body elongate. Suckers well developed. Esophagus and prepharynx lacking. Pharynx well developed. Ceca extending anteriorly alongside pharynx before turning posteriorly, extending to near posterior end of body. Testes tandem. Genital pore opening ventrally near posterior end of body. Cirrus sac containing cirrus, pars prostatica, and internal seminal vesicle. Ovary spherical, intertesticular. Seminal receptacle formed by expansion of Laurer canal. Uterus with extracecal loops in forebody, loops crossing dorsal to ventral sucker. Metraterm short, straight, not very muscular. Vitelline follicles extending in 2 lateral extracecal fields nearly entire length of body. Excretory pore dorsal, between genital pore and level of posterior testis, surrounded by glands free in the parenchyma. Excretory bladder short and narrow, bifurcating anteroventral to excretory pore. Type species Pojmanskia riosae $\mathrm{n}$. sp.

\section{Pojmanskia riosae n. sp.}

(Figs. 4-6)

Description (based on 24 specimens, 17 mature specimens measured): Elongate body, tapers posteriorly, 1.5-2.5 (2.1) $\mathrm{mm}$ long by $0.7-1.0(0.9) \mathrm{mm}$ wide, maximum width at level of the ventral sucker Oral sucker subventral, 370-466 (435) long by 400-503 (455) wide. Prepharynx and esophagus absent. Pharynx 114-167 long by 144-198 wide. Oral sucker width:pharynx width ratio 1:0.34-0.43 (1:0.41). Intestinal bifurcation immediately posterior to pharynx, ceca running anteriad to level of midpharynx before descending posteriad. Cecal length $83-92 \%(89 \%)$ of TBL. Forebody $34-37 \%$ (36\%). Ventral sucker $370-$ 562 (469) long by 370-562 (470) wide. Oral sucker:ventral sucker ratio 1:0.93-1.12 (1:1.01). Testes tandem, anterior testis located 63-65\% (63.4\%) TBL from anterior end of body, 122-323 (228) long by 141266 (222) wide, posterior testis located $80-81 \%$ (81\%) TBL from anterior, 114-323 (264) long by 118-66 (230) wide. Cirrus sac 110-175 (147) long by 46-90 (69) wide (Fig. 5). Genital pore, opening ventrally near posterior end. Ovary, spherical, intertesticular, 114-209 (174) long by 91-198 (163) wide. Mehlis gland posterior to ovary, dorsal to seminal receptacle. Seminal receptacle formed by saccate expansion of Laurer canal, separated from ovary by Mehlis gland and ootype, opening into ootype distal from common vitelline duct (Fig. 6). Uterus extending anteriorly from ootype along dextral side of body, overlapping ceca ventrally; uterine loops dorsal to ventral sucker, with extracecal loops in forebody to midlevel of oral sucker, 11-15.0\% (14\%) TBL from anterior end, extending posteriorly dorsal to ventral sucker, ventrally over gonads with extracecal uterine loops symmetrically on both sides of body, then medially between testes and dextral side of body, with some uterine loops posterior to ootype complex. Metraterm 95114 (105) long by 38-57 (48) wide, never overlapping ceca, surrounded by small gland cells on surface and large gland cells free in parenchyma. Vitelline fields extending from $12-19 \%(16 \%)$ TBL from anterior end to $64-78 \%(72 \%)$ TBL from anterior end. Eggs operculated, tanned, golden brown to dark brown in color 18-24 (22) long by 13-17 (15) wide. Excretory pore dorsal, between genital pore and level of posterior testis, surrounded by glands free in the parenchyma. Excretory bladder short and narrow, bifurcating anteroventral to excretory pore.

\section{Taxonomic summary}

Type host: Thryothorus pleurostictus (Passeriformes: Troglodytidae). Other hosts: Euphonia hirundinacea (Passeriformes: Thraupidae), Caryothraustes poliogaster (Passeriformes: Emberizidae), Platyrinchus coronatus (Passeriformes: Tyrannidae), T. nigricapillus (Passeriformes: Troglodytidae), and Morococcyx erythropygius (Cuculiformes: Cuculidae).

Prevalence, intensity, and site of infection: Euphonia hirundinacea ( 1 of 2; 3 immature worms; small intestine); C. poliogaster ( 1 of $2 ; 1$ worm; small intestine); $P$. coronatus ( 1 of $1 ; 1$ worm; gallbladder); $T$. pleurostictus ( 1 of $9 ; 6$ worms; gallbladder); T. nigricapillus (1 of $4 ; 1$ worm; gallbladder; $M$. erythropygius ( 1 of $1 ; 8$ worms; rectum and body washings [host intestine perforated by shot]).

Type locality: Cafetal $\left(10^{\circ} 51^{\prime} 13^{\prime \prime} \mathrm{N} ; 8^{\circ} 36^{\prime} 32^{\prime \prime} \mathrm{W} ; 320\right.$ m elevation).

Other localities: Estacion San Gerardo $\left(10^{\circ} 52^{\prime} 50^{\prime \prime} \mathrm{N} ; 85^{\circ} 23^{\prime} 21^{\prime \prime} \mathrm{W}\right.$; $605 \mathrm{~m}$ elevation).

Type material: Holotype, USNPC no. 93194; paratypes, USNPC no. 93195.

Etymology: The genus is named after Prof. Teresa Pojmanska, W. Stefanski Institute of Parasitology, Polish Academy of Sciences, in recognition of her many contributions to digenean taxonomy. The species is named after Sra. Petrona Rios, ACG parataxonomist, in recognition of her outstanding efforts on behalf of the parasite inventory.

\section{Remarks}

Using Pojmanska's (2002a, 2002b) recent keys to the Brachylaimoidea, we are unable to place the new species in any family. It would appear to be most similar to members of the Leucochloridiiae because it has well-developed suckers, equatorial ventral sucker, gonads, and a genital pore in the posterior part of the body; lacks an esophagus; and has ceca running immediately anteriad from intestinal bifurcation to the anterior level of the pharynx and vitelline follicles extending anteriorly to the level of the oral sucker. These features distinguish it from members of the Panopistidae, whose members are characterized by vitelline follicles not extending anteriorly to the anterior margin of the ventral sucker, and the Leucochloridiomorphidae, whose members possess a pretesticular ovary. The new species cannot be placed within the Leucochloridiidae sensu Pojmanska (2002a, 2002b), however, because it possesses ventral genital pores. In this regard, $\mathrm{P}$. riosae resembles $\mathrm{Mi}$ chajlovia spp., but differs in having genital sacs that contain both the seminal vesicle and pars prostatica.

\section{DISCUSSION}

We noted above that both $B$. moragai and $P$. riosae closely resemble members of the Leucochloridiidae. If we emend the family diagnosis to accommodate them, and if we reallocate Michajlovia to the family, as originally proposed by Pojmanska (1973), again emending the family diagnosis, the key presented 

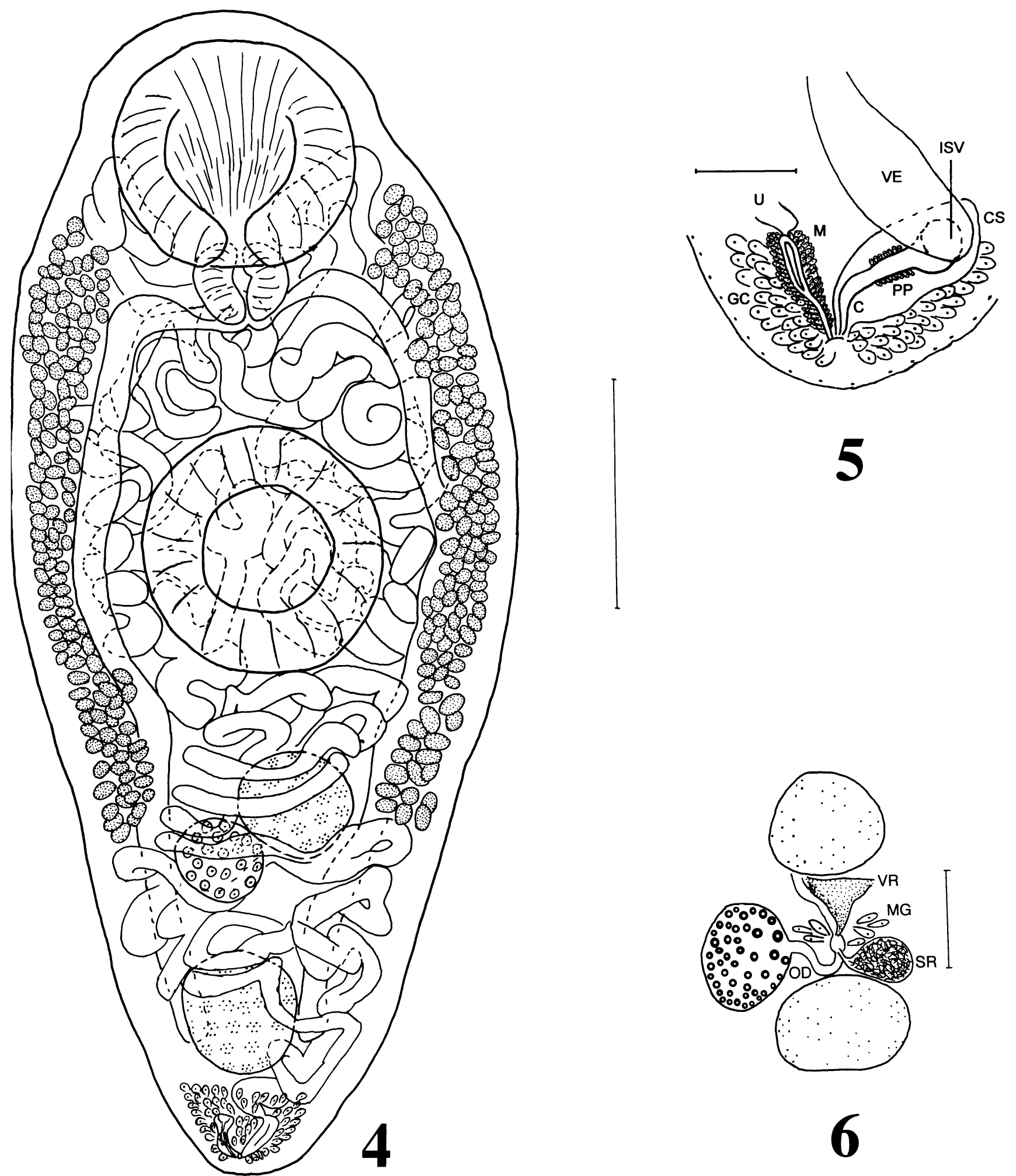

Figures 4-6. Pojmanskia riosae sp. n. 4. Ventral view of whole mount. Bar $=500 \mu \mathrm{m}$. 5. Terminal male reproductive complex, dorsal view. Bar $=100 \mu \mathrm{m} . \mathrm{CS}=$ cirrus sac; $\mathrm{GC}=$ gland cells free in parenchyma; ISV = internal seminal vesicle; $\mathbf{M}=$ metraterm (note additional small gland cells adhering to outer wall); $\mathrm{PP}=$ pars prostatica; $\mathrm{U}=$ uterus; $\mathrm{VE}=$ vas efferens. 6. Female reproductive complex ventral view. $\mathrm{Bar}=$ $100 \mu \mathrm{m} . \mathrm{MG}=$ Mehlis gland; OD = oviduct; $\mathrm{SR}=$ seminal receptacle; VR = vitelline reservoir. 
by Pojmanska (2002b) can be modified easily by adding 3 couplets as follows:

1a. Genital pores terminal . . . . . . . . . Bakkeius n. gen.

1b. Genital pores nonterminal . . . . . . . . . . . . . 2

2a. Genital pores ventral $\ldots \ldots \ldots \ldots \ldots \ldots \ldots \ldots \ldots \ldots$

2b. Genital pores dorsal . . . . . . . . . . . . . . . . 4

3a. Seminal vesicle inside cirrus sac ........Pojmanskia $\mathrm{n}$. gen.

3b. Seminal vesicle outside cirrus sac .............. . . . . . . . . . . . . Michajlovia Pojmanska, 1973

4a. Body elongate, suckers relatively small, in anterior region of body . . . . . . . . . . . . . . . . . Urotocus Looss, 1899

4b. Body oval, suckers well developed; ventral sucker in middle third of body . .................. 5

5a. Cirrus sac small; uterus with 2 ascending and 2 descending limbs, crossing body horizontally posterior to ventral sucker Urogonimus Monticelli, 1888

5b. Cirrus sac well developed; uterus with 1 ascending and 1 descending limb, crossing body anterior to ventral sucker . .

Leucochloridium Carus, 1835

This underscores the value of presenting taxonomic keys and identification guides in an electronic (i.e., on-line via the Internet) version, as emphasized in Brooks (2003, and references therein). In this case, the new information presented herein could have been integrated with previous information rapidly and effectively. We also note that because Michajlovia spp., B. moragai, and $P$. riosae bear such a striking resemblance to members of Leucochloridium, it is possible that a phylogenetic analysis might discover that the species constituting all 3 of these genera are nested within Leucochloridium (which already has 4 subgenera recognized-Pojmanksa, 2002b), necessitating major taxonomic revision of the group.

Both species of leucochloridiids were found in the intestine as well as the bile ducts and gallbladders of their avian hosts. If, like most parasites, these species are resource specialists (Brooks and McLennan, 1993, 2002; Adamson and Caira, 1994; Radtke et al., 2002), the key host resource may be localized in different parts of the intestinal tract in the different hosts. Alternatively, this could reflect responses by the parasites to 2 related but independent variables, a physiological preference for bile salts, associated initially with metacercarial excystment and activation, as well as the need to track food in the host intestine to gain nutrition.

The 10 avian host species reported here are, with 1 exception (Cuculiiformes: $M$. erythropygius), passerine birds of 5 different families. All 10 species are insectivores, some with broad diet preferences including many invertebrates, but none has ever been described eating molluscs (Skutch, 1954, 1960, 1972, 1981; Stiles, 1983; Stiles and Skutch, 1989). The feeding behavior of this group of hosts is diverse; they range from ground feeders (M. erythropygius), insect hunters of the jungle understory (H. leucosticta, $P$. coronatus), a general insectivore $(T$. pleurostictus), a fruit and berry specialist (E. hirundinacea), and bark gleaners ( $T$. nigricapillus, $C$. poliogaster) to very specialized hunters of invertebrates fleeing the movement of army ants (G. leucaspis, P. mcleannani). Moreover, bill morphologies and feeding behavior patterns of this group of hosts make it further unlikely that any of these birds could be very efficient in removing snail bodies from shells or snipping infected antennae from infected snails' heads. Thus, if the intermediate hosts are molluscs, it is likely that the avian hosts are eating the entire intermediate host. Owing to reduced calcium levels in the soils, most tropical snails have thin-walled shells, perhaps making it easier for avian gizzards to crush them. In addition, nonshelled pulmonate molluscs ("slugs") might be a likely food source for this group of birds, and the numerous feeding records (e.g., Stiles and Skutch 1989) for these birds specializing on "caterpillars" possibly relate to slugs rather than lepidopteran larvae. The behavior associated with catching beetles and caterpillars could be used for slugs as well.

Finally, infected passerine hosts of B. moragai were collected primarily at sites with abundant running water and associated riparian vegetation (Cafetal, Estacion Caribe, and Estacion San Gerardo), and almost all were taken at the start of the rainy season (June). Uninfected specimens of the same host species were collected at other times of the year and at other localities having different elevations (some higher, some lower) and different habitat characteristics. Similarly, infected passerine hosts of $P$. riosae were collected at sites with abundant running water in both rainy and dry seasons. The positive record from the nonpasserine host, $M$. erythropygeius, was anomalous in that it was taken at the driest site (Santa Rosa) and at the beginning of the wet season.

Our data suggest that infected intermediate hosts of B. moragai are closely associated with the wettest habitats we sampled (San Gerardo and Cafetal), whereas those of $P$. riosae prefer marginally drier habitats of the same regions. The diversity of host-habitat preferences, feeding behavior patterns, and morphologies suggest that the intermediate host of $L$. riosae is common and broadly distributed or that there is more than 1 intermediate host. Furthermore, we find it significant that most positive records of these digeneans are from specimens collected at the beginning of the rainy season. Specimens collected at other times and other localities and in comparable numbers showed similar parasite loads but were infected with other digeneans and other helminths. In summary, B. moragai and $P$. riosae are likely to be seasonally abundant in the rainy season in avian hosts on the basis of the yet-unknown ecology of their intermediate hosts and likely have short resident times in the hosts on the basis of the lack of positive records in other seasons.

\section{ACKNOWLEDGMENTS}

We are grateful to the scientific and technical staff of the ACG for support of this study, in particular Elda Araya, Roger Blanco, Carolina Cano, Maria Marta Chavarría, Felipe Chavarría, Roberto Espinoza, Dunia Garcia, Guillermo Jimenez, Elba Lopez, Sigifredo Marin, Alejandro Masis, Calixto Moraga, Fredy Quesada, and Petrona Rios. We also thank Dan Janzen and Winnie Hallwachs, scientific advisers to the ACG, for their support. Host specimens were collected by D.C., Jeremiah Trimble (Museum of Comparative Zoology [MCZ]), and Calixto Moraga (ACG) under the authority of CITES Permit US9258251, CITES Permit CR9123440, Costa Rica Ministero del Ambiente y Energia Licencia 203640283 and Resoluciones 215-2001-OFAU and 4112001-OFAU, Harvard University IACUC Protocol 21-09, and USDA APHIS Permit 47956 (Form VS16-6A). Host necropsy and parasite collections were made by D.R.B., D.C., Elda Araya, Sara Brant, Marie Causey, Ben Hanelt, Calixto Moraga, and Petrona Rios. This study was funded by a research grant from the Natural Sciences and Engineering Research Council (NSERC) of Canada to D.R.B. and by a grant from the MCZ Putnam Expedition Fund to D.C.

\section{LITERATURE CITED}

Adamson, M. L., AND J. N. CAIRA. 1994. Evolutionary factors influencing the nature of parasite specificity. Parasitology 109: S85S95. 
BAKKe, T. A. 1980. A revision of the family Leucochloridiidae Poche (Digenea) and studies on the morphology of Leucochloridium paradoxum Carus, 1835. Systematic Parasitology 1: 189-202.

Brooks, D. R. 2003. Parasite systematics in a new age of discovery. Journal of Parasitology. [In press.]

- AND D. A. McLennan. 1993. Parascript: Parasites and the language of evolution. Smithsonian Institution Press, Washington, D.C., $429 \mathrm{p}$

— AND 12002 . The nature of diversity: An evolutionary voyage of discovery. University of Chicago Press, Chicago, Illinois, $668 \mathrm{p}$.

MooRE, J. 2002. Parasites and the behaviour of animals. Oxford University Press, Oxford, U.K., 315 p.

POJMANSKA, T. 1967. Varuability of Leucochloridium paradoxum Carus $(=L$. heckerti Kagan, 1950) in natural and experimental conditions. Acta Parasitologia Polonica 14: 381-398.

1969. Leucochloridium perturbatum sp. n. (Trematoda: Brachylaimoidea), morphology, individual variability and life cycle. Acta Parasitologica Polonica 16: 153-175.

2002a. Superfamily Brachylaimoidea Joyeux \& Foley, 1930. In Keys to the Trematoda, D. I. Gibson, A. Jones, and R. A. Bray (eds.). CAB International and The Natural History Museum, London, U.K., p. 31-36.

2002b. Family Leucochloridiidae Poche, 1907. In Keys to the trematoda, D. I. Gibson, A. Jones, and R. A. Bray (eds.). CAB International and The Natural History Museum, London, U.K., p. $47-51$.

RadtKe, A., D. A. Mclennan, AND D. R. Brooks. 2002. Evolution of host specificity in Telorchis spp. (Digenea: Plagiorchiformes: Telorchiidae). Journal of Parasitology 88: 874-879.

Skutch, A. F. 1954. Life histories of Central American birds. Cooper Ornithological Society Pacific Coast Avifauna, no. 31. 448 pp. - 1960. Life histories of Central American birds, II. Cooper Ornithological Society Pacific Coast Avifauna, no. 34.593 pp.

- 1972. Studies of tropical American birds. Publications of the Nuttall Ornithology Club, no. 10. 228 pp.

. 1981. New studies of tropical American birds. Publications of the Nuttall Ornithology Club, no. 19. 281 pp.

Stiles, F. G. 1983. Birds. In Costa Rican natural history, D. H. Janzen (ed.). University of Chicago Press, Chicago, Illinois, p. 502-530. , AND A. F. SKUTCH. 1989. A guide to the birds of Costa Rica. Cornell University Press, Ithaca, New York, $511 \mathrm{p}$.

ZAMPARO, D., D. R. BROOKS, AND D. CAUSEY. 2003a. Whallwachsia illuminata n. g., n. sp. (Trematoda: Digenea: Plagiorchiformes: Prosthogonimidae) in the steely-vented hummingbird Amazilia saucerrottei (Aves: Apodiformes: Trochilidae) and the yellow-olive flycatcher Tolmomyias sulphurescens (Aves: Passeriformes: Tyrannidae) from the Area de Conservación Guanacaste, Guanacaste, Costa Rica. Journal of Parasitology 89: 814-818. 